\title{
HIV virology and pathogenetic mechanisms of infection: a brief overview
}

\author{
Emanuele Fanales-Belasio $^{(\mathrm{a})}$, Mariangela Raimondo ${ }^{(\mathrm{b})}$, Barbara Suligoi ${ }^{(\mathrm{b})}$ and Stefano Buttò ${ }^{(\mathrm{a})}$ \\ ${ }^{(a)}$ Centro Nazionale AIDS, Istituto Superiore di Sanità, Rome, Italy \\ ${ }^{(b)}$ Centro Operativo AIDS, Dipartimento di Malattie Infettive, Parassitarie ed Immunomediate, \\ Istituto Superiore di Sanità, Rome, Italy
}

\begin{abstract}
Summary. Studies on HIV virology and pathogenesis address the complex mechanisms that result in the HIV infection of the cell and destruction of the immune system. These studies are focused on both the structure and the replication characteristics of HIV and on the interaction of the virus with the host. Continuous updating of knowledge on structure, variability and replication of HIV, as well as the characteristics of the host immune response, are essential to refine virological and immunological mechanisms associated with the viral infection and allow us to identify key molecules in the virus life cycle that can be important for the design of new diagnostic assays and specific antiviral drugs and vaccines. In this article we review the characteristics of molecular structure, replication and pathogenesis of HIV, with a particular focus on those aspects that are important for the design of diagnostic assays.
\end{abstract}

Key words: HIV, virus replication, antigenic variation, virulence.

Riassunto (La virologia dell'HIV e i meccanismi patogenetici dell' infezione: una breve panoramica). Gli studi sulla virologia e la patogenesi dell'HIV sono importanti per comprendere i complessi meccanismi che regolano l'infezione della cellula da parte del virus e la distruzione del sistema immunitario. Questi studi si focalizzano sulle caratteristiche della struttura e della replicazione di HIV e sui meccanismi di interazione con l'ospite. Infatti, l'aggiornamento continuo di questi aspetti della biologia dell'HIV è fondamentale, poiché può portare all'identificazione di nuove molecole che giocano un ruolo chiave nella patogenesi del virus e che possono indirizzare nuovi campi di ricerca per la generazione di farmaci, vaccini e nuovi saggi diagnostici. Questo breve articolo riassume brevemente le attuali conoscenze sulle caratteristiche molecolari, del ciclo replicativo e della patogenesi dell'HIV, dando particolare rilievo ad aspetti che risultano importanti per l'allestimento di saggi diagnostici.

Parole chiave: HIV, replicazione del virus, variazione antigenica, virulenza.

\section{INTRODUCTION}

HIV virology and pathogenetic mechanisms of infection are continuously being investigated. A detailed understanding of HIV structure and how it establishes infection and causes AIDS are crucial not only to identify and develop new effective drugs and vaccines, but also to define strategies for the laboratory diagnosis of HIV infection. HIV testing is a critical step that allows to control HIV spreading in the population. Laboratory diagnostic strategies have to be continuously revised according to new discoveries on the replication characteristics and the pathogenetic mechanisms of HIV infection.

\section{STRUCTURE AND REPLICATION OF HIV}

Human Immunodeficiency Virus (HIV) isolates are currently grouped into two types, HIV-type 1 (HIV-1) and HIV-type 2 (HIV-2). The worldwide main agent of AIDS is HIV-1, while HIV-2 is re- stricted to some regions of Western and Central Africa. HIV is a genetically related member of the Lentivirus genus of the Retroviridae family. Infections with lentiviruses typically show a chronic course of the disease, with a long period of clinical latency, persistent viral replication and involvement of the central nervous system.

The retrovirus genome is composed of two identical copies of single-stranded RNA molecules [1] and is characterized by the presence of structural genes gag, pol, env. HIV-1 and HIV-2 viruses differ in the organisation of their genome, although the basic structure (i.e. the presence of the three structural genes, gag, pol and env) is the same one as for all retroviruses. In fact, in addition to having these three genes, the HIV-1 and HIV-2 genomes present a complex combination of other regulatory/accessory genes (Figure 1).

Both viruses potentially cause AIDS, though disease of the central nervous system may be more fre- 
A

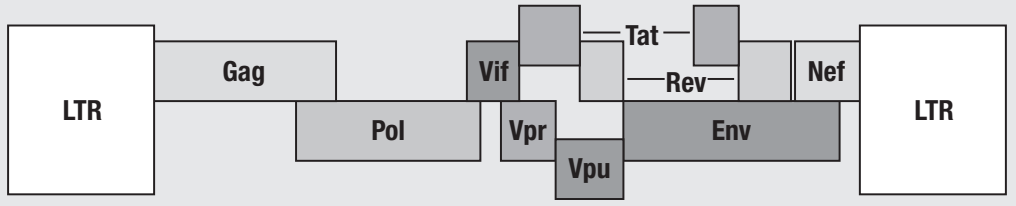

B

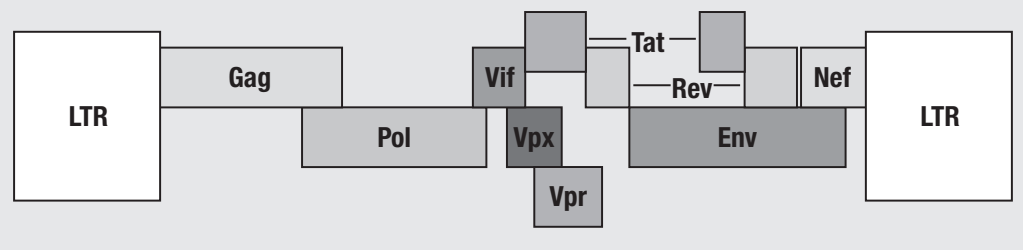

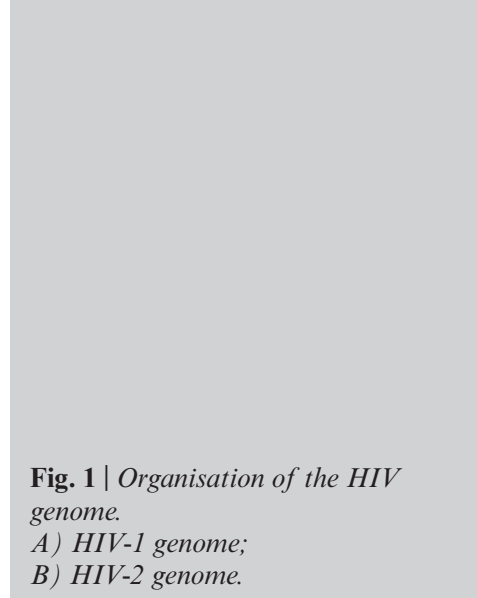

quent in HIV-2 infection [2]. In addition, HIV-2 appears less virulent than HIV-1 and infection course takes longer to progress to AIDS [3].

The structure of the HIV particle is similar for both HIV-1 and HIV-2 and is shown in Figure 2. Similarly to other retroviruses, the gag gene encodes the structural proteins of the core (p24, p7, p6) and matrix (p17) and the env gene encodes the viral envelope glycoproteins gp120 and gp41, which recognize cell surface receptors. The pol gene encodes for enzymes crucial for viral replication, which are the reverse transcriptase that converts viral RNA into DNA, the integrase that incorporates the viral DNA into host chromosomal DNA (the provirus) and the protease that cleaves large Gag and Pol protein precursors into their components.

HIV viral particles have a diameter of $100 \mathrm{~nm}$ and are surrounded by a lipoprotein-rich membrane. Each viral particle membrane includes glycoprotein heterodimer complexes composed of trimers of the external surface gp120 and the transmembrane spanning gp41 glycoproteins bound together. The binding between gp120 and gp41 is not covalent and therefore the gp120 may be shed spontaneously within the local environment and detected in the serum, as well as within the lymphatic tissue of HIVinfected patients. During the process of budding from the infected cell (see later), the virus may also incorporate into its membrane different proteins from the host cell membrane, such as HLA class I and II proteins, or adhesion proteins such as ICAM-1 that may facilitate adhesion to other target cells. A matrix protein (p17) is anchored to the inside of the viral lipoprotein membrane. Virus membrane and the matrix protein include the capsid composed of polymers of the core antigen (p24). The capsid contains two copies of HIV RNA combined with a nucleoprotein and the enzymes reverse transcriptase, integrase and protease (reviewed in ref. [4]).

HIV viruses are characterised by other accessory/ regulatory genes that play key roles in modulating virus replication (reviewed in ref. [5]). Among these,

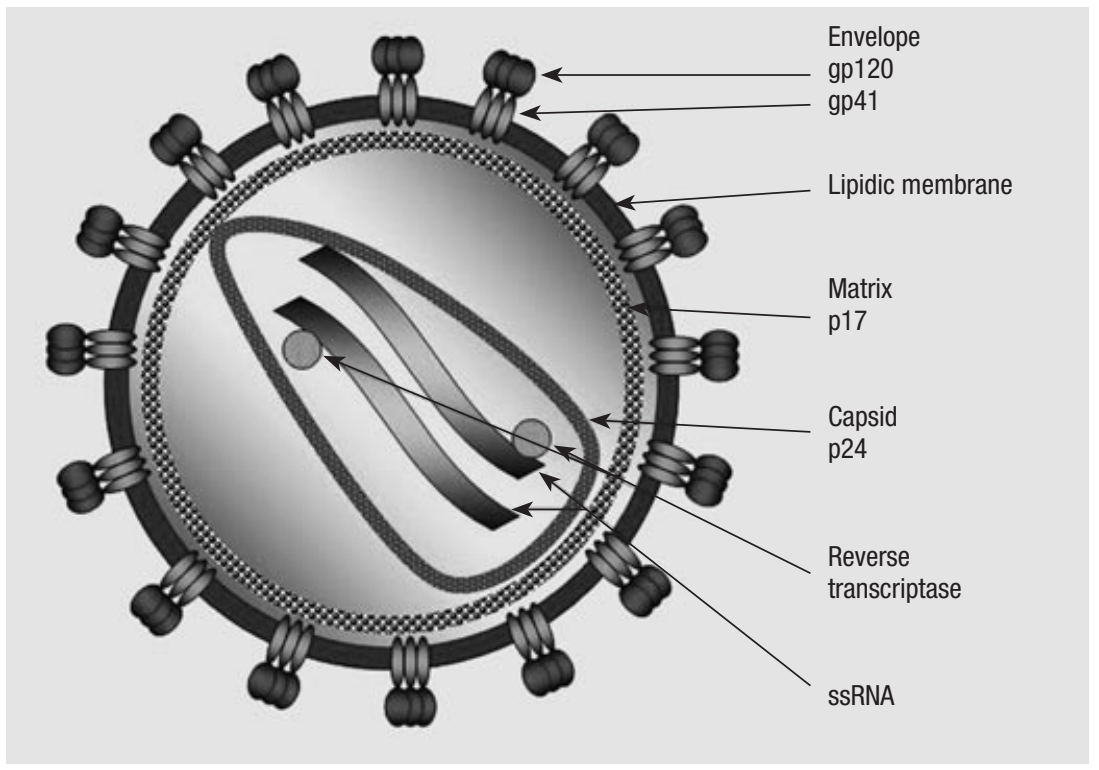

Fig. 2 Structure of the $H I V-1$ particle. SsRNA: single strand RNA. 


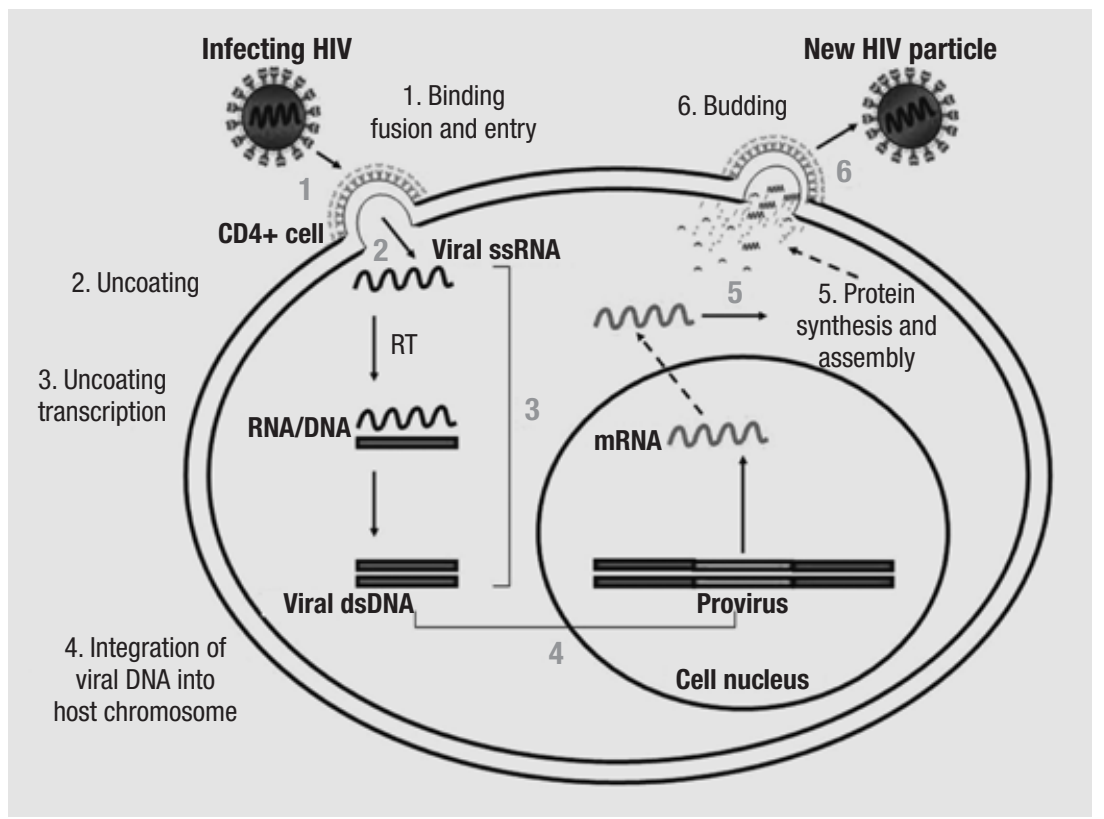

Fig. 3 | HIV replication cycle. $R T$ : reverse transcriptase; dsDNA: double strand DNA.

the tat gene encodes for a protein (Tat) that is expressed very early after infection and promotes the expression of HIV genes. The Rev protein, coded by the rev gene, ensures the export from nucleus to cytoplasm of the correctly processed messenger and genomic RNA. The function of the other accessory HIV proteins is less well understood; it is believed that the $\mathrm{Vpr}$ protein is involved in the arrest of the cell cycle. This protein also enables the reverse transcribed DNA to gain access to the nucleus in non-dividing cells such as macrophages, a function that is performed by Vpx in HIV-2. Vpu is a protein necessary for the correct release of virus particle, whereas the vif gene codes for a small protein (Vif) that enhances the infectiveness of progeny virus particles. Finally, the Nef protein has multiple functions including cellular signal transduction and the down regulation of the $\mathrm{CD} 4$ receptor on the cell surface to allow virus budding in the late stages of the virus replication cycle.

\section{THE HIV REPLICATION CYCLE}

The HIV replication cycle is schematically shown in Figure 3. It can be summarised in six steps; 1) binding and entry; 2) uncoating; 3 ) reverse transcription; 4) provirus integration; 5) virus protein synthesis and assembly and 6) budding.

The entry pathway of HIV-1 and HIV-2 can be divided into three major events: virus binding to the cell, activation and fusion (Figure 4). The viral envelope trimeric complex, composed of the heterodimer proteins gp120 and gp41, is essential for virus recognition and entry into target cells. Indeed, the gp41 subunit contains a fusogenic hydrophobic peptide at its amino terminus, which is essential for

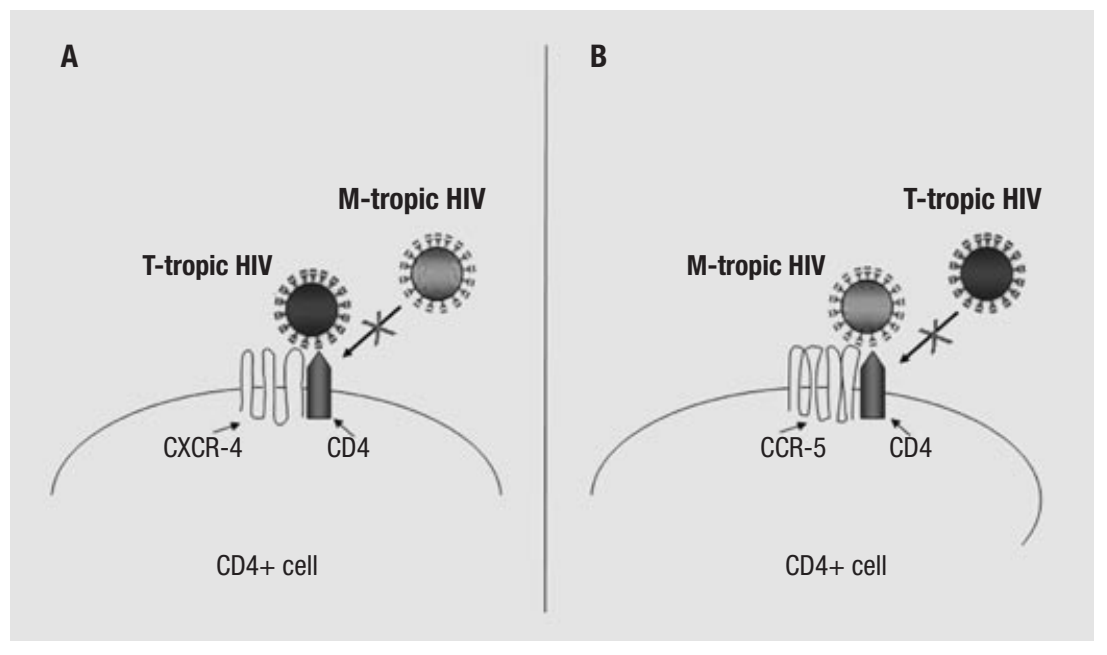

Fig. $4 \mid$ HIV tropism. M-tropic HIV: monocytelmacrophagetropic HIV;

T-tropic HIV: T-lymphocyte-tropic HIV. 
fusion of the viral and cellular membranes [6]. HIV gp120 binds a $58 \mathrm{kDa}$ monomeric glycoprotein, designed as CD4, which is expressed on the cell surface of about $60 \%$ of circulating T-lymphocytes, on T-cell precursors within the bone marrow and thymus, on monocytes/macrophages, eosinophils, dendritic cells and microglial cells of the central nervous system. The CD4 molecule normally functions as a co-receptor of the major histocompatibility complex class II molecule during T-cell recognition of a foreign antigen [7]. Upon gp120 binding with the CD4 protein, the virus envelope complex undergoes a structural change, exposing a specific domain in the gp120 able to bind chemokine receptors on the cell membrane. These molecules are recognized by chemotactic cytokines, i.e. chemokines, small proteins that mediate the homing and recruitment of immune cells in the course of inflammation. These receptors are classified on the basis of the position of disulfide-like cysteine residues, as well as their angiogenic effects. At least 17 members of these chemokine ligands, working as HIV coreceptors, have been identified so far. They are classified according to the structure of their ligands and the current nomenclature uses CXC, CC, CX3C or $\mathrm{C}$ followed by $\mathrm{R}$ (receptor) and a number (e.g., CXCR1-5, CCR1-10, CX3CR1, etc). Most common coreceptors used by HIV are CXCR4 and CCR5, but other potential coreceptors have been described [8]. The $\alpha$-chemokine SDF-1 (stromal cell-derived factor 1) is the natural ligand of CXC4, whereas CCR5 is a receptor for the $\beta$-chemokine family (RANTES, macrophage inflammatory proteins [MIP]-1- $\alpha$ and MIP-1- $\beta$ ). CXCR4 is expressed on many cells, including T-lymphocytes, whereas CCR5 is present on monocytes/macrophages, dendritic cells and activated T-lymphocytes.

The differential expression of chemokine receptors on cell targets has been shown to be a major determinant of the HIV-1 tropism [9] (Figure 4). In fact, there are strains of HIV-1 preferentially binding the $\beta$-chemokine receptor CCR 5 present mainly in macrophages and CD4+ T-cells expressing CCR5 [10]. These strains are also known as macrophagetropic (M-tropic) or R5 viruses. Of note, the chemokines RANTES, MIP-1- $\alpha$ and MIP-1- $\beta$, ligands for the CCR5 receptor, are able to suppress HIV-1 infection in vitro [11], because they compete with the virus for the binding to CCR5. CCR5 is used by almost all primary HIV-1 isolates regardless of viral genetic subtype. Conversely, other isolates use preferentially CXCR4 for entry and replicate in primary CD4+ T-cells that also express CXCR4. These strains are known as T-lymphocyte-tropic (T-tropic) or X4 viruses. The $\alpha$-chemokine SDF-1, a ligand for CXCR4, suppresses the replication of T-tropic HIV-1 viruses, by competing with the virus for the binding to the CXCR4. Finally, there are HIV isolates that are able to bind to both CCR 5 and CXCR4 receptors. These strains are termed dual tropic or X4R5 viruses.

The double binding of gp120 to both the CD4 and one chemokine receptor allows a more stable two- pronged attachment of the virus, which, in turn, allows the N-terminal fusion peptide gp41 to penetrate the cell membrane. The HR1 and HR2 repeat sequences in gp41 interact, causing the collapse of the extracellular portion of gp41 into a hairpin. This loop structure brings the virus and cell membranes close together, allowing fusion of the membranes and subsequent entry of the viral capsid.

Following membrane fusion, the virus core uncoats into the cytoplasm of the target cell freeing the viral RNA (uncoating) (Figure 3). The conversion of viral RNA into proviral DNA takes place because of the action of the reverse transcriptase and the integrase (Figure 3). Through its ribonuclease $\mathrm{H}$ active site, the reverse transcriptase begins the reverse transcription of viral RNA in the cytoplasm that occurs as a minus-strand polymerization, starting at the primer binding site, until viral RNA is transcribed into a RNA/DNA hybrid double helix. Then, the ribonuclease $\mathrm{H}$ site breaks down the RNA strand and the polymerase active site of the reverse transcriptase completes a complementary DNA strand to form a double helix DNA molecule, which is integrated within the cell genome by the enzyme Integrase. This protein cleaves nucleotides of each 3 ' ends of the double helix DNA creating two sticky ends, transfers the modified provirus DNA into the cell nucleus and facilitates its integration into the host genome. The integration of proviral DNA and the expression of the provirus require that target cell is in an activated state. Monocytes/macrophages, microglial cells, and latently infected quiescent CD4+ T-cells contain integrated provirus and are important long-living cellular reservoirs of HIV [12]. Upon cell activation, transcription of proviral DNA into a messenger RNA occurs (Figure 3 ). Transcription process initially results in the early synthesis of regulatory HIV-1 proteins such as Tat and Rev. Tat binds to the TAR site (Transactivation Response Element) at the beginning of the HIV-1 RNA in the nucleus and stimulates the transcription and the formation of longer RNA transcripts. Rev facilitates the transcription of longer RNA transcripts and the expression of structural and enzymatic genes and inhibits the production of regulatory proteins, therefore promoting the formation of mature viral particles.

Viral messenger RNA coding for long fragments migrates into the cytoplasm, where structural proteins of new virions are synthesized (Figure 3 ). The proteins coded by pol and gag genes form the nucleus of the maturing HIV particle; the gene products coded by the env gene form the glycoprotein spikes of the viral envelope. Large gp160 precursor molecules are, in fact, cleaved by the HIV-1 protease into gp120 and gp41. The Gag and Pol proteins are also derived from a large $160 \mathrm{kD}$ precursor molecule, from which the HIV protease cleaves the p24, p17, p9 and p7 Gag final products and the Pol proteins.

The cleavage of the precursor molecules by the HIV-1 Protease is necessary for the generation of infectious viral particles. The formation of new vi- 
ral particles is a stepwise process: two viral RNA strands associate together with replication enzymes, while core proteins assemble over them forming the virus capsid. This immature particle migrates towards the cell surface. The large precursor molecules are then cleaved by the HIV-1 protease, resulting in new infectious viral particles, which bud through the host cell membrane (Figure 3), thus acquiring a new envelope. During the budding process, the virus lipid membranes may incorporate various host cell proteins and become enriched with phospholipids and cholesterol. Differently from T-lymphocytes, where budding occurs at the cell surface and virions are released into the extracellular space, the budding process in monocytes and macrophages results in the accumulation of virions within intracellular vacuoles which are then released.

\section{HIV VARIABILITY}

Variability is the most powerful weapon of HIV, which allows the virus to overcome host immunity and the effects of therapeutic (drugs) and prophylactic (vaccines) interventions [13]. HIV variability is a consequence of at least three peculiar features: 1) the "error-prone" mechanism of action of the virus enzyme reverse transcriptase, that introduces, on average, one substitution per genome per replication round [14]; 2) the very rapid viral replication, that generates a high number of virions per day (estimated around $10^{10}$ ) in the infected individual [15] and 3) the occurrence of recombination processes between two or more different HIV viruses within the same infected individual.

Based on homologies among genomic sequences of HIV viruses, it is possible to distinguish two HIV types: HIV-1 and HIV-2. There are three major groups of $\mathrm{HIV}-1$, designed as $\mathrm{M}$ (Major), $\mathrm{O}$ (Outlier) and $\mathrm{N}$ (non-M/non-O). Group $\mathrm{M}$ includes 9 subtypes, or "clades", designed as A to K, which have spread with specific geographic distribution in the worldwide pandemic [16]. HIV-1 groups $\mathrm{O}$ and $\mathrm{N}$, in contrast, are largely confined in restricted areas as Gabon, Cameroon and neighbouring countries, close to the natural habitat of P.t. troglodytes [17]. The gene sequences of HIV-1 groups $\mathrm{M}, \mathrm{N}$ and $\mathrm{O}$ are as distinct from each other as they are from another lentivirus causing immunodeficiency in the chimpanzees, termed Simian Immunodeficiency Virus of chimpanzees (SIVcpz) [18].

Within subtypes A and F, at least 6 sub-subtypes (A1, A2, A3 and A4 and F1 and F2) can be distinguished. Occasionally, two viruses of different subtypes can infect the same cell and share their genetic material, thus resulting in new hybrid mosaic viruses (a process similar to sexual reproduction, and sometimes called "viral sex"). Many of these new strains are not replicating, but those able to be shed and trasmitted are known as "circulating recombinant forms" or CRFs. For example, the CRF A/B is a mixture of subtypes A and B. Finally, a variety of
Unique Recombinant Forms (URFs) have been described. These forms are mosaic viruses that have not spread from their original location [19]. The classification of HIV strains into subtypes, CRFs and URFs is a quite complex issue and the definitions are subject to change as new discoveries occur. Further, viruses within the same HIV-1 subtype may differ by up to $20 \%$, and in places such as Africa, where there are multiple subtypes, the sequences of highly variable envelope proteins can differ among them up to $38 \%$.

HIV-2 is endemic in West Africa, but has spread to Europe (especially Portugal) and to India. Like HIV-1, HIV-2 can be subdivided into a number of major groups, which appear to represent separate zoonoses from a primate host. In this case the primate reservoir was not a great ape (the chimpanzee) but a West African monkey, the sooty mangabey, which can be infected by another SIV (SIVsmm).

In Sub-Saharan Africa there is the widest HIV-1 heterogeneity with the presence of all known subtypes, groups and recombinant forms, but subtypes $\mathrm{A}$ and $\mathrm{C}$ are the most prevalent. Furthermore, in Western Africa also HIV-2 strains are present. In Southern and East Africa, HIV-1 subtype C is the most represented virus. HIV-1 subtype $\mathrm{C}$ is also largely widespread in India with almost 6 million persons infected. Recombinant forms are present both in Sub-Saharan Africa and in South-East Asia; in particular, the recombinant form CRF01_AE has been described in Thailand, Cambodia, Vietnam, Malaysia, China, Taiwan, Korea and Japan. Subtype B viruses are mostly prevalent in North and South America, Central and Western Europe, and Australia. Subtype D is diffused, together with subtype A, in East Sub-Saharan Africa (Uganda, Tanzania and Kenya). Subtype A is also present in Eastern Europe, mainly in children. Some recombinant forms circulate in Argentina (CRF12_BF e CRF17_BF) and in Brazil (CRF29_BF e CRF31_ $\mathrm{BF})$. Finally, in East Europe the recombinant virus CRF03_AB is circulating among injecting drug users. Although the prevalence of other circulating CRFs and URFs worldwide has not fully investigated, some data indicate that the number of these forms is rapidly growing.

\section{NATURAL COURSE AND PATHOGENESIS OF HIV INFECTION}

The pathogenesis of HIV infection and the progression to AIDS are a consequence of the properties of the infecting virus isolate and the host's immune response to the virus. The balance between the effectiveness of these two components determines the different outcome of the infection, from development of AIDS to long-term survival.

HIV cannot survive outside the bloodstream or lymphatic tissue. Furthermore, virus is easily inactivated by the exposure to common detergents and disinfectants. Thus, virus transmission requires the 
directed exposition to infected blood or secretions in the presence of skin damage, i.e. by needles or sharp tools, or abrasions in mucosal tissues within sexual intercourses [20]. Transmission of HIV is highly dependent on the biologic properties of the virus isolate, its concentration in the infected body fluid, and, finally, host susceptibility.

HIV is mainly integrated or replicating into the infected cells, which are the main vehicles of virus transmission [21]. In fact, HIV-infected cells can transfer the virus to cells of the local immune system (e.g., T-cells, macrophages, dendritic cells), as well as cells lining vaginal or anorectal mucosae.

In the case of infection acquired through heterosexual intercourse, which is the most common route of infection worldwide, the cervix mucosa is the first tissue being infected [22]. Here, dendritic cells and CD4+ lymphocytes can be infected through receptor-dependent mechanisms and allow virus spreading to regional lymph nodes and subsequently into the bloodstream. Viral replication within the lymphatic tissue of infected mucosae and regional lymph nodes is already extensive in the early stages of the infection [23, 24]. In particular, virus particles can be found within follicular dendritic cells (FDC), macrophages, and activated CD4+ T-cells, which are the main targets of infection. Infected cells can undergo lysis or allow the establishment of latent infection, particularly in macrophages and resting CD4+ T-cells, which are permanent viral reservoirs [25]. This represents a great obstacle in the complete eradication of the infection since it allows virus persistence also in the presence of effective regimens of highly active anti retroviral treatment.

After 10-12 days from infection, virus RNA is detectable in the blood by RT-PCR amplification methods [26] (Figure 5). The onset of viremia in plasma is a critical time point in the natural history of HIV infection because it indicates that infected individual has acquired the potential of transmitting the infection [27-29] and provides the first chance to diagnose the infection in the blood sample [30-33].
HIV RNA plasmaviremia levels rapidly and predictably increase up to a peak level over 100 million copies per cubic centimetre, approximately in the phase of antibody seroconversion [26, 30, 34] (Figure 5). These high levels of HIV-1 viremia are normally short-lived, since the host generates humoral and cellular immune responses that partly control viral replication. Over the following weeks, viremia declines by several orders of magnitude until it reaches a lower steady level (viral setpoint) or drops under detection level [35]. Several factors associated with innate and acquired antiviral immunity can influence viral replication and the establishment of a viral setpoint during this phase of infection (often referred as "acute infection"). However, the role of the virus-specific cell-mediated immune response, in particular, of the specific CD8+ T-cell cytotoxic activity, seems to be central in the initial control of virus replication at this stage of the infection, before the appearance of anti-HIV binding and/or neutralising antibodies [36-40].

The time of appearance of first HIV specific antibodies (seroconversion) has been estimated by detecting their presence in sequential samples from patients with accurate information on the time of HIV infection, starting from the first day of exposure. Using commercially available third generation tests, seroconversion has been observed to occur in a period ranging from 3 to 5 weeks, with an average of 22 days (reviewed in [41]). A more detailed description of kinetics of HIV antibody appearance is described elsewhere in this monography [42].

Thus, the time period in which the infection is present, but antibodies are not detectable, yet, can be referred as the serological "window period". However, in rare occasions infected individuals could result seronegative over 3 months after virus transmission, indicating that in some circumstances the generation of HIV-specific antibodies may require a longer period [43].

Ranging from few days to few weeks since exposure to HIV, most of the infected individuals present

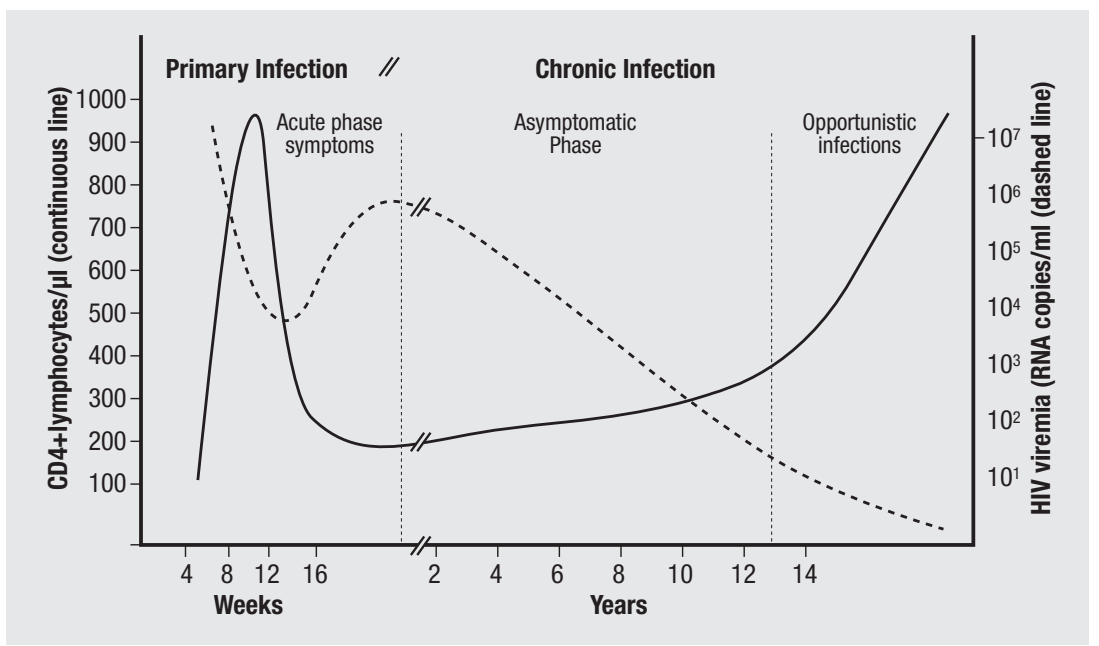

Fig. 5 | Clinical course of HIV infection. 
symptoms resembling flu-like or mononucleosis-like illness, as fever, maculopapular rash, oral ulcers, lymphadenopathy, arthralgia, pharyngitis, malaise, weight loss and myalgia [35]. These clinical features are quite heterogeneous and it has been reported that individuals who display more severe and durable symptoms in the course of acute infection tend to progress more rapidly to AIDS [44-46]. The symptomatic phase of acute HIV-1 infection lasts between 7 and 10 days, and rarely longer than 14 days. During acute HIV-1 infection, the number of CD4+ T-cells dramatically declines, in association with high viremia levels, before the onset of antiviral immune response [47]. When specific immune response has been elicited, HIV viremia drops and CD4+ Tcells raise again, although to levels lower than those present before infection, suggesting the persistence of virus-associated pathogenic effects (Figure 5). In addition, qualitative functional impairment of immune responses to HIV and other antigens can be detected [48-51], indicating that the virus induces, very early after infection, a dysfunction of CD4+ Tcells and of other cells of the immune system.

Few weeks after the onset of acute infection, most of the infected individuals enter into a clinical asymptomatic period, generally associated with the drop of HIV viremia levels and absence of symptoms (Figure 5). This event reflects primarily the antiviral action exerted by both innate and adaptive immune responses [52]. In particular, antibodies specifically bind to HIV antigens, determining the prevention of cell infection (neutralization of infectivity) [53], or favouring the elimination of infected cells by a mechanism known as AntibodyDependent Cellular Cytotoxicity (ADCC), mediated by T-lymphocytes and natural killer cells [54]. In addition, HIV-specific T-lymphocytes recognize virus antigens on the surface of infected cells and promote their elimination by antigen-specific cytotoxic mechanisms [36]. Indeed, in the course of asymptomatic phase, HIV continuously replicates in the body compartments, counteracting antiviral immunity and inducing a state of chronic systemic inflammation. There are several reasons why antiviral immunity is not able to eradicate the infection. Among them, the persistence of integrated virus in lymphoid compartments (reservoir), with low expression of virus antigens and the high frequency of mutations within virus genome, which leads to escape from the immune system, are the most effective mechanisms. Thus, virus replication keeps occurring in the lymphoid compartment, and transitory peaks of HIV-viremia can be detected in plasma also in absence of symptoms related to the infection [52]. In some infected individuals, HIV viremia is not detectable for many years, indicating the occurrence of an efficient control of the infection. Individuals displaying this condition have been termed as elite "controllers" $[55,56]$ and are intensely studied with the aim of understanding the mechanisms involved in the control of HIV infection.
In the course of the asymptomatic period, HIV-associated pathogenic effects persist and induce a slow but progressive loss of CD4+ lymphocytes and impairment of the immune system [52]. The progression of the disease is characterized by the destruction of the lymphoid tissue architecture, which is a consequence of the virus replication and of the chronic activation of the cells of immune system. This leads to an increase of virus diffusion to surrounding CD4+ T-cells and favours HIV-1 spread within local, regional and whole lymphoid environment. Particularly at this stage, HIV infection is associated with an extensive replication in the gut lamina propria and submucosa and in draining lymph nodes, with local depletion of CD4+ T-cells [57, 58].

The further progression of the disease depends on the capacity of the host to contain virus replication and to reconstitute the pool of memory Tcells within the mucosa associated lymphoid tissue or lymph nodes. In absence of virus containment, the destruction of the lymphoid system proceeds and CD4+ T-cell number continues to drop to levels $(<200 \mathrm{cells} / \mu \mathrm{l})$ which determine the risk of onset of opportunistic infections by bacteria, viruses, fungi and parasites, and tumours, as a consequence of a serious impairment of the immune system [59]. The most common opportunistic infections, which define the AIDS stage, are caused by Microcystis carinii, Candida albicans, Cytomegalovirus, Herpes zoster or enteropathic parasites (Criptosporidium and Giardia species, Isospora belli), which can determine life-threatening diseases [59]. This phase is usually characterized by diffuse lymph node swelling, severe reduction of body weight, fever and respiratory and gastro-intestinal symptoms. A progressive encephalopathy, induced by HIV or other opportunistic infections, is also associated with a severe invalidation and increased risk of mortality. Neoplastic diseases, as Kaposi is Sarcoma and lymphomas, most likely emerging as consequence of the immunodeficiency status, also severely weaken the organism, worsening the clinical course of the disease [60]. During the AIDS phase, the number of CD4+ T-cells continues to decrease (Figure 5) and anaemia and marked lymphopenia are frequently detected. Based on the latest evidence, UNAIDS/WHO estimate that, in the absence of treatment, the mean time from the infection onset to AIDS-related death, is approximately 11 years (Figure 5). Of course, the progression of the disease is extremely variable, depending on the infecting virus isolate and the antiviral response of the host. Beside the above described "elite controllers", who can adequately control HIV infection, infected individuals are classified, based on infection course, with non-standardized definitions as "progressors", "rapid progressors", "non progressors" and "long term non progressors". It is evident that this distinction is based mainly on clinical evaluation and mirrors the individual response to HIV infection.

For many years the nature of the factors associated with antiviral protection has been investigated, 
focusing on cohorts of "elite controllers" and "long term non progressors", and experimental infection of monkey models. Indeed, the role of some genetic markers, specific individual haplotypes and peculiar immune response patterns, has been evaluated [61, 62]. However, at present, no correlates or mechanism of protection against HIV infection have been definitely recognized. Furthermore, vaccine studies that have been performing in the last 20 years have not provided satisfactory results due to virus extreme variability and escape mechanisms from the immune system [63]. The characterization of the factors involved in the protection against HIV infection could allow the development of effective vaccine formulations able to counteract virus epidemic and AIDS-related mortality, particularly in developing countries, where antiviral treatment is not widely available.

\section{CONCLUSIONS}

Although HIV-1 has been the most studied infectious agent in the last 30 years, the new available technologies have allowed the acquisition of new information about virus structure and replication.

\section{References}

1. Luciw PA. Human immunodeficiency virus and their replication. In: Fields BN, Knippe DM, Howley PM (Ed.). Field virology. Philadelphia: Lippincott-Raven; 1996. p. 1881-952.

2. Lucas, SB, Hounnou A, Peacock C, Beaumel A, Djomand G, N'Gbichi JM, Yeboue K, Hondé M, Diomande M, Giordano C, Doorly R, Brattegaard K, Kestens L, Smithwick R, Kadio A, Ezani N, Yapi A, De Cock KM. The mortality and pathology of HIV infection in a west African city. AIDS 1993; 7:1569-79.

3. Whittle H, Morris J, Todd J, Corrah T, Sabally S, Bangali J, Ngom PT, Rolfe M, Wilkins A. HIV-2-infected patients survive longer than HIV-1-infected patients. AIDS 1994;8:1617-20.

4. Gelderblom HR, Ozel M, Pauli G. Morphogenesis and morphology of HIV. Structure-function relations. Arch Virol 1989;106:1-13

5. Emerman M, Malim MH. HIV-1 regulatory/accessory genes: keys to unraveling viral and host cell biology. Science 1998;280:1880-4.

6. Weiss RA. Cellular receptors and viral glycoproteins involved in retrovirus entry. In: Levy JA (Ed.). The Retroviridae (vol. 2). New York, USA: Plenum Press; 1993. p. 1-108.

7. Miceli MC, Parnes JR. Role of CD4 and CD8 in T cell activation and differentiation. Adv Immunol 1993;53:59-122.

8. Alkhatib G, Berger EA. HIV coreceptors: from discovery and designation to new paradigms and promise. Eur J Med Res 2007;12:375-84.

9. Broder CC, Berger E. Fusogenic selectivity of the envelope glycoprotein is a major determinant of human immunodeficiency virus type 1 tropism for CD4+ T-cell lines vs. primary macrophages. Proc Natl Acad Sci 1995;92:9004-8.

10. Coakley E, Petropoulos CJ, Whitcomb JM. Assessing chemokine co-receptor usage in HIV. Cur Opin Infect Dis 2005; 18:9-15.
Further, studies on the different viral subtypes and recombinant forms have shown that marked differences in the infection cycle may occur based on the phylogenetic and geographic origin of HIV isolates. This is key for the design of new preventive and therapeutic approaches aimed at counteracting molecules essential for virus cycle. These acquisitions have also enabled the development of updated diagnostic methodologies aimed at an earlier and more accurate detection of virus antigens and virusspecific antibodies in biological samples. Based on these new available methods, the procedures for the diagnosis of HIV infection need to be subjected to revisions to allow early detection of virus-specific antigens or antibodies, which are essential for both limitation of virus spread and application of timely treatment regimens.

\section{Acknowledgements}

We thank P. Sergiampietri for the excellent editorial assistance.

Submitted on invitation.

Accepted on 4 January 2010.

11. Garzino-Demo A. Chemokines and defensins as HIV suppressive factors: an evolving story. Curr Pharm Des 2007; 13:163-72.

12. Chun TW, Carruth L, Finzi D, Shen X, Di Giuseppe JA, Taylor H, Hermankova M, Chadwick K, Margolick J, Quinn TC, Kuo YH, Brookmeyer R, Zeiger MA, BarditchCrovo P, Siliciano RF. Quantification of latent tissue reservoirs and total body viral load in HIV-1 infection. Nature 1997;387:183-8

13. Menéndez-Arias L. Targeting HIV: antiretroviral therapy and development of drug resistance. Trends Pharmacol Sci 2002;23:381-8.

14. Sarafianos SG, Marchand B, Das K, Himmel DM, Parniak MA, Hughes SH, Arnold E. Structure and function of HIV1 Reverse Transcriptase: molecular mechanisms of polymerization and inhibition. J Mol Biol 2009;385:693-713.

15. Ho DD. Perspectives series: host/pathogen interactions. Dynamics of HIV-1 replication in vivo. J Clin Invest 1997; 99:2565-7.

16. UNAIDS. 2008 Report on the global AIDS epidemic, UNAIDS. Available from: http://search.unaids.org/Results. aspx?d=en \&q=report + on + global+aids + epidemic $+2008 \& \mathrm{c}$ $=\& 1=\mathrm{en} \& \mathrm{~s}=\mathrm{f}$.

17. Peeters M, Gueye A, Mboup S, Bibollet-Ruche F, Ekaza E, Mulanga C, Ouedrago R, Gandji R, Mpele P, Dibanga G, Koumare B, Saidou M, Esu-Williams E, Lombart JP, Badombena W, Luo N, Vanden Haesevelde M, Delaporte E. Geographical distribution of HIV-1 group $\mathrm{O}$ viruses in Africa. AIDS 1997;11:493-8.

18. Gao F, Bailes E, Robertson DL, Chen Y, Rodenburg CM, Michael SF, Cummins LB, Arthur LO, Peeters M, Shaw GM, Sharp PM, Hahn BH. Origin of HIV-1 in the chimpanzee Pan troglodytes troglodytes. Nature 1999;397:436-41.

19. Carr JK, Avila M, Gomez Carrillo M, Salomon H, Hierholzer J, Watanaveeradej V, Pando MA, Negrete M, 
Russell KL, Sanchez J, Birx DL, Andrade R, Vinoles J, McCutchan FE. Diverse BF recombinants have spread widely since the introduction of HIV-1 into South America. AIDS 2001;15:F41-7.

20. Suligoi B, Raimondo M, Fanales-Belasio E, Buttò S. The epidemic of HIV infection and AIDS, promotion of testing, and innovative strategies. Ann Ist Super Sanità 2010;46:1523.

21. Martin N, Sattentau Q. Cell-to-cell HIV-1 spread and its implications for immune evasion. Curr Opin HIV AIDS 2009; 4:143-9.

22. Lekkerkerker AN, van Kooyk Y, Geijtenbeek TB. Viral piracy: HIV-1 targets dendritic cells for transmission. Curr HIV Res 2006;4:169-76.

23. Embretson J, Zupancic M, Ribas JL, Burke A, Racz P, Tenner-Racz K, Haase AT. Massive covert infection of helper $\mathrm{T}$ lymphocytes and macrophages by HIV during the incubation period of AIDS. Nature 1993;362:359-62.

24. Pantaleo G, Graziosi C, Demarest JF, Butini L, Montroni M, Fox CH, Orenstein JM, Kotler DP, Fauci AS. HIV infection is active and progressive in lymphoid tissue during the clinically latent stage of disease. Nature 1993;362:355-8.

25. Alexaki A, Liu Y, Wigdahl B. Cellular reservoirs of HIV-1 and their role in viral persistence. Curr HIV Res 2008;6:388400.

26. Fiebig EW, Wright DJ, Rawal BD, Garrett PE, Schumacher RT, Peddada L, Heldebrant C, Smith R, Conrad A, Kleinman SH, Busch MP. Dynamics of HIV viremia and antibody seroconversion in plasma donors: implications for diagnosis and staging of primary HIV infection. AIDS 2003;17:1871-9.

27. Busch MP, Satten GA. Time course of viremia and antibody seroconversion following human immunodeficiency virus exposure. Am J Med 1997;102:117-24.

28. Ling AE, Robbins KE, Brown TM, Dunmire V, Thoe SY, Wong SY, Leo YS, Teo D, Gallarda J, Phelps B, Chamberland ME, Busch MP, Folks TM, Kalish ML. Failure of routine HIV-1 tests in a case involving transmission with preseroconversion blood components during the infectious window period. JAMA 2000;284:210-4.

29. Kopko PM, Fernando LP, Bonney EN, Freeman JL, Holland PV. HIV transmissions from a window-period platelet donation. Am J Clin Pathol 2001;116:562-6.

30. Lindbäck S, Thorstensson R, Karlsson AC, von Sydow M, Flamholc L, Blaxhult A, Sönnerborg A, Biberfeld G, Gaines H. Diagnosis of primary HIV-1 infection and duration of follow-up after HIV exposure. Karolinska Institute Primary HIV Infection Study Group. AIDS 2000;14:2333-9.

31. Hecht FM, Busch MP, Rawal B, Webb M, Rosenberg E, Swanson M, Chesney M, Anderson J, Levy J, Kahn JO. Use of laboratory tests and clinical symptoms for identification of primary HIV infection. AIDS 2002;16:1119-29.

32. Holodniy M, Busch M. Establishing the diagnosis of HIV infection. In: Dolin R, Masur H, Saag M (Ed.). AIDS therapy. 2nd. New York: Churchill Livingstone (Elsevier); 2002. p. 3-20.

33. Nguyen KA, Busch MP. Evolving strategies for diagnosing human immunodeficiency virus infection. Am J Med 2000;109:595-7.

34. Little SJ, McLean AR, Spina CA, Richman DD, Havlir DV. Viral dynamics of acute HIV-1 infection. J Exp Med 1999;190:841-50

35. Kahn JO, Walker BD. Acute human immunodeficiency virus type 1 infection. N Engl J Med 1998;339:33-9.

36. Bangham CR. CTL quality and the control of human retroviral infections. Eur J Immunol 2009;39:1700-12.
37. Koup RA. Virus escape from CTL recognition. $J$ Exp Med 1994;180:779-82.

38. Borrow P, Lewicki H, Hahn BH, Shaw GM, Oldstone MB. Virus-specific CD8+ cytotoxic T-lymphocyte activity associated with control of viremia in primary human immunodeficiency virus type 1 infection. J Virol 1994;68:6103-10.

39. Price DA, Goulder PJ, Klenerman P, Sewell AK, Easterbrook PJ, Troop M, Bangham CR, Phillips RE. Positive selection of HIV-1 cytotoxic T lymphocyte escape variants during primary infection. Proc Natl Acad Sci USA 1997;94:1890-5.

40. Allen TM, O'Connor DH, Jing P, Dzuris JL, Mothé BR, Vogel TU, Dunphy E, Liebl ME, Emerson C, Wilson N, Kunstman KJ, Wang X, Allison DB, Hughes AL, Desrosiers RC, Altman JD, Wolinsky SM, Sette A, Watkins DI. Tat-specific cytotoxic $\mathrm{T}$ lymphocytes select for SIV escape variants during resolution of primary viraemia. Nature 2000;407:386-90.

41. Buttò S, Raimondo M, Fanales-Belasio E, Suligoi B. Suggested strategies for the laboratori diagnosis of HIV infection in Italy. Ann Ist Super Sanità 2010;46:34-41.

42. Buttò S, Suligoi B, Fanales-Belasio E, Raimondo M. Laboratory diagnostics for HIV infection. Ann Ist Super Sanità 2010;46:2433 .

43. Weber B. Screening of HIV infection: role of molecular and immunological assays. Expert Rev Mol Diagn 2006;6:399-411.

44. Vanhems P, Lambert J, Cooper DA, Perrin L, Carr A, Hirschel B, Vizzard J, Kinloch-de Loës S, Allard R. Severity and prognosis of acute human immunodeficiency virus type 1 illness: a dose-response relationship. Clin Infect Dis 1998;26:323-9.

45. Pedersen C, Nielsen JO, Dickmeis E, Jordal R. Early progression to AIDS following primary HIV infection. AIDS 1989;3:45-7.

46. Keet IP, Krijnen P, Koot M, Lange JM, Miedema F, Goudsmit J, Coutinho RA. Predictors of rapid progression to AIDS in HIV-1 seroconverters. AIDS 1993;7:51-7.

47. Gupta KK. Acute immunosuppression with HIV seroconversion. N Engl J Med 1993;328:288-9.

48. Rosenberg YJ, Anderson AO, Pabst R. HIV-induced decline in blood CD4/CD8 ratios: viral killing or altered lymphocyte trafficking? Immunol Today 1998;19:10-7.

49. Lichterfeld M, Kaufmann DE, Yu XG, Mui SK, Addo MM, Johnston MN, Cohen D, Robbins GK, Pae E, Alter G, Wurcel A, Stone D, Rosenberg ES, Walker BD, Altfeld M. Loss of HIV-1-specific CD8+ T cell proliferation after acute HIV-1 infection and restoration by vaccine-induced HIV-1specific CD4+ T cells. J Exp Med 2004;200:701-12.

50. Douek DC. Disrupting T-cell homeostasis: how HIV-1 infection causes disease. AIDS Rev 2003;5(3):172-7.

51. Lange CG, Lederman MM, Medvik K, Asaad R, Wild M, Kalayjian R, Valdez H. Nadir CD4+ T-cell count and numbers of $\mathrm{CD} 28+\mathrm{CD} 4+\mathrm{T}$-cells predict functional responses to immunizations in chronic HIV-1 infection. AIDS 2003;17:2015-23.

52. Ford ES, Puronen CE, Sereti I. Immunopathogenesis of asymptomatic chronic HIV Infection: the calm before the storm. Curr Opin HIV AIDS 2009;4:206-14.

53. Stamatatos L, Morris L, Burton DR, Mascola JR. Neutralizing antibodies generated during natural HIV1 infection: good news for an HIV-1 vaccine? Nat Med 2009; 15:866-70.

54. Chung A, Rollman E, Johansson S, Kent SJ, Stratov I. The utility of ADCC responses in HIV infection. Curr HIV Res 2008;6:515-9.

55. Baker BM, Block BL, Rothchild AC, Walker BD. Elite control of HIV infection: implications for vaccine design. Expert Opin Biol Ther 2009;9:55-69. 
56. Saksena NK, Rodes B, Wang B, Soriano V. Elite HIV controllers: myth or reality? AIDS Rev 2007;9:195-207.

57. Brenchley JM, Schacker TW, Ruff LE, Price DA, Taylor JH, Beilman GJ, Nguyen PL, Khoruts A, Larson M, Haase AT, Douek DC. CD4+ T cell depletion during all stages of HIV disease occurs predominantly in the gastrointestinal tract. $J$ Exp Med 2004;200:749-59.

58. Mehandru S, Poles MA, Tenner-Racz K, Horowitz A, Hurley A, Hogan C, Boden D, Racz P, Markowitz M. Primary HIV-1 infection is associated with preferential depletion of CD4+ T lymphocytes from effector sites in the gastrointestinal tract. J Exp Med 2004;200:761-70.

59. Brooks JT, Kaplan JE, Holmes KK, Benson C, Pau A, Masur H. HIV-associated opportunistic infections-going, going, but not gone: the continued need for prevention and treatment guidelines. Clin Infect Dis 2009;48:609-11.
60. Clifford GM, Franceschi S. Cancer risk in HIV-infected persons: influence of CD4(+) count. Future Oncol 2009; 5:669-78.

61. Piacentini L, Biasin M, Fenizia C, Clerici M. Genetic correlates of protection against HIV infection: the ally within. $J$ Intern Med 2009;265:110-24.

62. Letvin NL. Correlates of immune protection and the development of a human immunodeficiency virus vaccine. Immunity 2007;27:366-9.

63. International AIDS Vaccine Initiative (IAVI). AIDS Vaccine Blueprint 2008: A Challenge to the Field, A Roadmap for Progress. IAVI (August 2008). Available from: www.iavi.org/ Lists/IAVIPublications/attachments/750bc28e-0e47-4a1e91bf-eeea7c8bb98e/IAVI_AIDS_Vaccine_Blueprint_2008_ ENG.pdf. 